\title{
KARAKTERISTIK PENGATURAN PEMBATASAN TIMBULAN SAMPAH PLASTIK SEKALI PAKAI PADA PERGUB BALI NO.97/2018 : PENDEKATAN PARTISIPASI MASYARAKAT
}

\author{
I Kadek Wira Dwipayana, Fakultas Hukum Universitas Udayana, e-mail: \\ wira.dwipayana1999@gmail.com \\ Kadek Agus Sudiarawan, Fakultas Hukum Universitas Udayana, e-mail: \\ agus_sudiarawan@unud.ac.id
}

doi: https://doi.org/10.24843/KS.2020.v08.i08.p04

\begin{abstract}
ABSTRAK
Tulisan ini merupakan tulisan yang memiliki tujuan agar dapat menyampaikan informasi mengenai upaya pelestarian lingkungan hidup melalui partisipasi masyarakat dengan mengurangi penggunaan plastik sekali pakai (PSP). Tulisan ini memuat bahasan mengenai karakteristik pengaturan peran masyarakat dalam Pergub Bali No.97/2018 serta relevansinya dengan pengurangan sampah plastic sekali pakai (PSP) di Bali. Metode penelitian yang digunakan adalah metode penelitian hukum normatif dengan pendekatan peraturan perundang-undangan, konseptual serta analitis. Sumber bahan hukum pada tulisan ini berasal dari sumber bahan hukum primer dan sekunder dengan teknik pengumpulan data melalui studi literatur sumber bahan hukum. Setelah dianalisis, ditemukan hasil mengenai karakterisik pengaturan peran masyarakat yang berupa hak dan kewajiban yang dimuat didalam peraturan tersebut. Namun meskipun demikian ditemukan juga beberapa kelemahan dari peraturan tersebut yang dapat membuat dilanggarnya peraturan tersebut.
\end{abstract}

Kata Kunci : Peraturan Gubernur Bali No.97/2018, Lingkungan Hidup, Partisipasi Masyarakat

\begin{abstract}
This paper was aimed at conveying information about environmental conservation efforts through community participation by reducing the use of disposable plastics (PSP). It contained a discussion of the characteristics of community role regulation in the Governor of Bali No. 97/2018 and its relevance to reducing disposable plastics (PSP) waste in Bali. The research method used was a normative legal research method with a statutory, conceptual and analytical approach. The source of legal material in this study came from primary and secondary legal material sources with data collection techniques through the study of legal source literature sources. After being analyzed, it was found regarding the characteristics of the regulation of community roles in the form of rights and obligations contained in the regulation. However, there were also some weaknesses in the regulation which were able to make the regulation violated.
\end{abstract}

Keywords : Bali Governor's Regulation No.97/2018, Environment, People Partisipation.

\section{Pendahuluan}

1.1. Latar Belakang Masalah

Suatu kesatuan antara makhluk hidup dan benda mati yang menjalin hubungan serta membentuk suatu pola perilaku dalam sebuah ekosistem merupakan pengertian secara mendasar tentang lingkungan hidup. Dasar hukum yang mengatur mengenai hal tersebut di Indonesia adalah Undang-Undang RI No.32/2009 Tentang 
Perlindungan dan Pengelolaan Lingkungan Hidup (untuk seterusnya disebut UU PPLH). Dalam peraturan itu, pengertian mengenai lingkungan hidup termuat pada pasal 1 angka 1. Dari penjelasan dasar tadi, bisa kita ketahui bahwa pola perilaku manusia juga akan berdampak pada lingkungannya. Maka dari itu dapat dikatakan bahwa perilaku manusia merupakan salah satu faktor penting dalam menjaga kelestarian lingkungannya sendiri.

Kerusakan lingkungan pada hakikatnya bisa disebabkan oleh karena 2 (dua) hal. Pertama, penyebab kerusakan lingkungan hidup berasal dari alam itu sendiri melalui tragedi alam yang meliputi banjir bandang, angin puting beliung, gempa dan yang lainnya. Kedua, penyebab kerusakan lingkungan hidup berasal dari kontribusi manusia itu sendiri melalui perilaku dan kegiatan mereka. Kerusakan itu biasanya terjadi ketika manusia sedang melakukan kegiatan sehari-hari mereka. Telah diketahui bersama bahwa manusia digolongkan sebagai makhluk sosial, artinya manusia yang satu harus hidup berdampingan dengan yang lainnya baik dalam kehidupan pribadi maupun kehidupan bermasyarakat. Didalam kehidupannya itu kerap timbul kegiatankegiatan yang bisa merusak lingkungannya. Misalnya dalam menjaalankan kehidupannya manusia sering menimbulkan sampah dan kemudian sampah yang dihasilkan itu dibiarkan begitu saja, padahal bisa saja sampah itu merubah kandungan material dilingkungannya.

Sampah adalah sisa kegiatan sehari-hari manusia dan/atau proses alam yang berbentuk padat. ${ }^{1}$ Permasalahan sampah di Indonesia rasanya tidak kunjung selesai dan membuat sebagian masyarakat merasa kesal. Itu karena jumlah sampah di Indonesia kian waktu kian meningkat. Sampah sebagai hasil dari kegiatan yang dilakukan manusia terbagi menjadi sampah organik dengan presentase $60-70 \%$ serta sampah anorganik dengan presentase 30-40\% dengan komposisi terbesarnya adalah sampah plastik yaitu berkisar 14\%.2 Jambeck, 2015 menyatakan bahwa Indonesia masuk dalam peringkat kedua dunia setelah China menghasilkan sampah plastik diperairan mencapai 187,2 juta ton. ${ }^{3}$ Indonesia mendapatkan peringkat itu karena Indonesia menghasilkan jumlah sampah yang cukup fantastis yaitu mencapai jumlah 64 juta ton pada tiap tahunnya dengan komposisi terbanyak adalah sampah organik dengan presentase $60 \%$ yang selanjutnya diduduki oleh sampah plastik dengan presentase mencapai $14-15 \% .{ }^{4}$ Meskipun presentase sampah plastik jika diperhatikan memang terbilang kecil dibandingkan dengan presentase sampah organik, namun perting kita ketahui Satu buah sampah plastik perlu berkisar antara 20-100 tahun untuk bisa terurai. Selain itu penelitian mengungkapkan penggunaan plastik yang tidak sesuai syarat akan menyebabkan gangguan kesehatan yang bisa memicu timbulnnya kanker dan kerusakan jaringan pada tubuh manusia (karsinogenik). ${ }^{5}$ Maka, diperlukan adanya tindakan segera untuk mengurangi tibulan sampah plastik

1 Takdir, Rahmadi, Hukum Lingkungan di Indonesia, (Jakarta, PT. Raja Grafindo Persada, 2012), 77.

2 Purwaningrum, Pramiati. "Upaya mengurangi timbulan sampah plastik di lingkungan." Indonesian Journal of Urban and Environmental Technology 8, no. 2 (2016): 141147.

$3 \quad$ Ibid,141-147.

4 Timbulan Sampah Nasional Capai 64 juta ton per Tahun, https://ekonomi.bisnis.com/read/20190221/99/891611/timbulan-sampah-nasional-capai64-juta-ton-per-tahun, diakses pada 24 Juli 2020: pukul 20.47 Wita.

5 Karuniastuti, Nurhenu. "Bahaya plastik terhadap kesehatan dan lingkungan." Swara Patra 3, no. 1 (2013): 6-14 
di Indonesia. Arne Naess menyatakan krisis lingkungan hidup dewasa ini hanya bisa diatasi dengan melakukan perubahan cara pandang dan perilaku manusia terhadap alam secara fundamental dan radikal. ${ }^{6}$ Dari pendapat tersebut bisa kita tarik sebuah spekulasi dimana dengan merubah pola prilaku masyarakat Indonesia untuk mengurangi penggunaan plastik maka secara tidak langsung juga dapat melestarikan lingkungan hidup.

Pasal 18 ayat (1) Undang-Undang Dasar Negara Republik Indonesia Tahun 1945 (UUD NRI 1945) yang menyatakan bahwa Negara Kesatuan Republik Indonesia dibagi atas daerah-daerah provinsi dan daerah provinsi itu dibagi atas kabupaten dan Kota, yang tiap-tiap provinsi, kabupaten, dan kota itu mempunyai pemerintahan daerah, yang diatur dengan undang-undang. Itu menandakan bahwa disetiap daerah terdapat pemerintah daerah yang akan memerintah daerahnya masing-masing. Pemerintah pusat akan mendelegasikan kewenangan kepada pemerintah daerah untuk mengurusi daerahnya sendiri. Meskipun terdapat pendelegasian kewenangan tersebut, bukan berarti pemerintah pusat tidak melakukan pengawasan terhadap pelaksanaan pemerintahan daerah it sendiri. Itu berarti kelestarian lingkungan juga menjadi tanggung jawab Pemerintah Daerah dan untuk menjaga dan melestarikannya Pmerintah Daerah juga memiliki kewenangan untuk membuat peraturan yang dapat menjaga daripada kelestarian lingkungan itu. Bali merupakan salah satu daerah yang tengah berupaya melestarikan lingkungan dengan mengupayakan pembatasan timbulan sampah plastik sekali pakai melalui Peraturan Gubernur Bali No.97 Tahun 2018 (untuk seterusnya disebut Pergub Bali No.97/2018). Yang menjadi alasan utama ditetapkannya peraturan tersebut karena Bali telah memproduksi sampah mencapai 4.281 ton per hari dan 11 persen diantaranya mengalir ke lautan. ${ }^{7}$ Jumlah sampah setiap tahun telah mencapai 1,5 juta dengan persentase 52 persen sampah tidak dikelola dibandingkan 48 persen yang dikelola. ${ }^{8}$ Berdasarkan penelitian yang dilakukan tahun 2017 di provinsi Bali oleh Departement Teknik Lingkungan Institut Teknologi Bandung (ITB) dan Danone-Aqua, produksi sampah plastik mencapai 268 ton setiap harinya dan hanya $29.4 \%$ sampah plastik yang dibuang ke tempat pembuangan akhir (TPA) ${ }^{9}$

Pergub Bali No.97/2018 memuat peran serta masyarakat sebagai upaya pengurangan sampah PSP. Untuk menghimbau masyarakat, Pemerintah Provinsi Bali telah melakukan komunikasi sosial. Dalam melaksanakan komunikasi sosial, Gubernur Bali melakukan kontak sosial secara primer (langsung) ataupun sekunder (media massa). ${ }^{10}$ Tujuan dilakukan komunikasi sosial tersebut adalah agar masyarakat ikut berpartisipasi dengan tidak melanggar peraturan tersebut. Berkaitan dengan hal tersebut maka, penulis berniat membuat suatu tulisan dengan mengangkat judul "KARAKTERISTIK PENGATURAN PEMBATASAN TIMBULAN SAMPAH PSP PADA PERGUB BALI NO.97/2018 : PENDEKATAN PARTISIPASI MASYARAKAT”.

6 Keraf, A. Sonny, Etika Lingkungan Hidup, (Jakarta, Penerbit Buku Kompas, 2010$), 2$.

7 Data dan Sumber Sampah di Bali Tahun 2019,https://balibersih.com/2019/07/04/datadan-sumber-sampah-di-bali-tahun-2019/, diakses pada 25 Juli 2020: pukul 14.17 Wita.

8 Aditya, I Gst. Ngr. Agung Krisna. "Pergub Bali Nomor 97 Tahun 2018 Dalam Paradigma Etika Ekosentrisme." Jurnal Ilmiah Widya Sosiopolitika 1, no. 2 (2019): 109-119.

9 Kubontubuh, Ekapria Dharana. "Bali Bebas Sampah Plastik (menuju "Clean and Green Island")." Jurnal Bali Membangun Bali 2, no. 1 (2019): 41-46.

10 Putri, Niluh Wiwik Eka. "Komunikasi Sosial dalam Mensosialisasikan Penetapan Kebijakan Gubernur Bali Tentang Pembatasan Timbulan Sampah Plastik Sekali Pakai." Jurnal Nomosleca 5, no. 1 (2019): 44-57. 
Sebelumnya penulis belum pernah melihat tulisan yang membahas mengenai karakteristik pengaturan pembatasan timbulan sampah plastik sekali pakai (PSP) pada Peraturan Gubernur Bali Nomor 97 Tahun 2018 dengan melalui pendekatan partisipasi masyarakat. Penulis mengangkat judul tersebut karena penulis melihat bahwa peran serta masyarakat merupakan salah satu dari sekian banyak elemen penting dalam mewujudkan kelestarian lingkungan khususnya dengan cara mengurangi timbulan sampah plastik sekali pakai (PSP).

\subsection{Rumusan Masalah}

Berdasarkan uraian latar belakang masalah tersebut di atas, maka dapat dirumuskan beberapa permasalahan sebagai berikut:

1. Bagaimanakah karakteristik pengaturan peran serta masyarakat dalam upaya pengurangan sampah plastic sekali pakai (PSP) yang termuat didalam Pergub Bali No.97 Tahun 2018?

2. Bagaimanakah relevansi pengaturan peran masyarakat dalam Pergub Bali No.97 Tahun 2018 terhadap upaya pengurangan sampah plastic sekali pakai (PSP) di Bali ?

\subsection{Tujuan Penulisan}

Penulisan artikel dalam jurnal ilmiah ini bertujuan untuk mengetahui karakteristik pengaturan peran serta masyarakat dalam upaya pengurangan sampah plastik sekali pakai (PSP) yang termuat didalam Pergub Bali No.97/2018. Selain itu penelitian ini juga bertujuan untuk mengetahui relevansi pengaturan peran masyarakat dalam Pergub Bali No.97/2018. terhadap upaya pengurangan sampah plastik sekali pakai (PSP) di Bali.

\section{Metode Penelitian}

Dalam membuat suatu tulisan, tentunya diperlukan adanya suatu metode penelitian untuk merangkum semua data yang diperlukan agara tulisan yang dibuat bisa memiliki hasil yang cukup akurat. Tulisan ini menggunakan metode penelitian hukum normatif yang dikenal juga dengan istilah metode penelitian hukum doktriner dengan tujuan meneliti suatu peraturan atau kaidah Pada penelitian ini, sering kali hukum dikonsepsikan sebagai apa yang tertulis dalam peraturan perundangundangan (Law in book) atau hukum yang dikonsepsikan sebagai kaidah atau norma yang merupakan patokan berperilaku masyarakat terhadap apa yang dianggap pantas. ${ }^{11}$ Penulis menggunakan pendekatan peraturan perundang-undangan, pendekatan konseptual serta pendekatan analisis. Sumber bahan hukum meliputi sumber bahan hukum primer serta sumber bahan hukum sekunder. Bahan hukum primer dan bahan hukum sekunder tersebut dianalisis secara kualitatif dalam kerangka berpikir yang diarahkan untuk mendapat jawaban atas permasalahan yang dikaji dalam penelitian ini dan hasilnya dituangkan dalam bentuk makalah. ${ }^{12}$ Adapun dalam mengumpulkan bahan hukum penulis gunakan teknik dengan studi literatur.

11 Efendi, S.H.I., M.H., Dr. Jonaedi dan Prof. Dr. Jhonny Ibrahim, S.H., S.E., M.M., M.Hum., Metode Penelitian Hukum Normatif dan Empiris Edisi Pertama, (Depok, Prenadamedia Group, 2016), 124.

12 Tjukup, I. Ketut, Dewa Nyoman Rai Asmara Putra, Nyoman A. Martana I. Putu Rasmadi, P. Arsha, and Kadek Agus Sudiarawan. "Penyelesaian Sengketa Lingkungan Hidup Melalui 


\section{Hasil dan Pembahasan}

\subsection{Karakteristik Pengaturan Peran Serta Masyarakat Dalam Upaya Pengurangan Sampah PSP Yang Termuat didalam Pergub Bali No.97/2018.}

Masyarakat merupakan sekumpulan atau kelompok manusia yang mendiami suatu kawasan atau wilayah yang dimana dalam menjalankan kehidupannya mereka saling ketergantungan dan membentuk suatu pola organisasi agar dapat mengatur tata kelola kehidupan bermasyarakat. Oleh karena manusia hidup bermasyarakat itulah sering terjadi kegiatan-kegiatan yang tanpa disadari dapat merusak lingkungan hidup padahal sejatinya masyarakat khususnya di daerah Bali harus menjaga hubungan harmonis dengan lingkungan hidup mereka. Sebagaimana telah diketahui bahwa masyarakat daerah Bali mengenal istilah Tri Hita Karana yaitu tiga penyebab tercapainya suatu kebahagiaan dan kedamaian bagi manusia yang merupakan warisan turun-temurun dari leluhur masyarakat Bali. Secara implisit Tri Hita Karana mengandung pesan agar dalam pengelolaan sumber daya alam dilakukan secara arif untuk menjaga kelestariannya, senantiasa bersyukur kehadapan Tuhan dan selalu mengedepankan keharmonisan hubungan antar sesama manusia, sehingga timbulnya konflik dapat diantisipasi. ${ }^{13}$ Namun dewasa ini kerap dijumpai tindakan yang dapat merusak lingkungan. Contohnya sering kali sampah rumah tangga dibuang begitu saja secara sembarangan tanpa memperhatikan akibat yang dapat ditimbulkan, terlebih lagi jika sampah yang dibuang tersebut merupakan sampah yang sukar atau sulit untuk terurai. Plastik sekali pakai (seterusnya disebut PSP) contohnya. Plastik yang terakumulasi cepat atau lambat memang akan terurai oleh sinar matahari (photodegrade). Namun perlu diperhatikan bahwa hal itu hanya bisa terjadi dalam kondisi kering. Apabila sampah plastik tersebut berada dalam keadaan basah, plastik hanya akan terpecah menjadi potongan-potongan yang lebih kecil, namun tetap menjadi polimer, bahkan sampai ke PE (Polyethylene) tingkat molekuler. ${ }^{14}$ Akhirnya sampah tersebut menimbulkan dampak negatif yang sangatlah luas bahkan tidak hanya bagi manusia, melainkan juga makhluk hidup lainnya karena dapat terkonsumsi. Dengan dikeluarkannya Pergub Bali No.97/2018 diharapkan dapat meminimalisir hal-hal tersebut.

Pergub Bali No.97/2018 merupakan peraturan daerah yang ditetapkan pada 21 Desember 2018. Peraturan ini memiliki tujuan yang baik sebagaimana telah termuat dalam pasal 2 huruf g dimana peraturan ini bertujuan sebagai pedoman Pemerintah Daerah dalam merumuskan suatu kebijakan dibidang pembatasan timbulan sampah PSP dengan mengikut sertakan masyarakat dalam mewujudkan suatu perlindungan terhadap lingkungan hidup. Pemerintah Daerah Bali juga mewajibkan seluruh pelaku usaha baik itu produsen, pemasok maupun distributor untuk menyediakan produk pengganti plastik sekali pakai (PSP) dan melarang peredaran PSP sebagaimana telah termuat dalam pasal 6 dan 7 Pergub Bali No.97/2018. Kendatipun demikian, ada masyarakat yang merasa bahwa peraturan tersebut merupakan suatu langkah awal

Mekanisme Acara Gugatan Perwakilan Kelompok (Class Action)." ADHAPER: Jurnal Hukum Acara Perdata 3, no. 2 (2018): 245-260.

13 Wesnawa, I. Gede Astra,"Penerapan Konsep Tri Hita Karana dalam Lingkungan Permukiman Perdesaan (Kasus Kabupaten Badung Provinsi Bali)." Jurnal Bumi Lestari 10, no. 2 (2010): 295-301.

14 Hasibuan, Rosmidah. "Analisis dampak limbah/sampah rumah tangga terhadap pencemaran lingkungan hidup." Jurnal Ilmiah Advokasi 4, no. 1 (2016): 42-52. 
untuk daerah Bali dalam menjaga kelestarian lingkungan hidup, namun tidak sedikit juga kalangan masyarakat yang merasa bahwa peraturan tersebut dapat mempersulit kegiatan masyarakat terlebih lagi bagi para pelaku usaha.

Dalam Pergub Bali No.97/2018 khususnya pada Bab V mengatur mengenai peran serta masyarakat sehingga dapat berpartisipasi dalam rangka mensukseskan tujuan daripada dibentuknnya peraturan tersebut. Secara umum partisipasi dapat dimaknai sebagai hak warga masyarakat untuk terlibat dalam proses pengambilan keputusan pada setiap tahapan pembangunan, mulai dari perencanaan, pelaksanaan, pengawasan, dan pelestarian. ${ }^{15}$ Peran masyarakat tersebut mencakup hak dan kewajiban. Masyarakat daerah bali berhak untuk menerima informasi yang akurat dan benar tentang alat atau bahan pengganti PSP yang ramah lingkungan dan berhak untuk tidak menerima untuk menggunakan PSP dari orang yang menyediakan PSP tersebut. Hak masyarakat tersebut telah termuat dalam ketentuan pasal 13 Pergub Bali No.97/2018. Perlu kita ketahui bahwa tentunya hak harus selalu bejalan sejajar dan seiringan dengan kewajiban, maka dari itu selain mendapatkan hak, masyarakat juga memiliki kewajiban yang harus dilakukan guna ikut berpartisipasi dalam rangka menyukseskan tujuan daripada dibentuknya Pergub Bali No.97/2018. Adapun kewajiban masyarakat yang terdapat dalam ketentuan pasal 14 Peraturan tersebut adalah masyarakat mengambil peran aktif dalam pembatasan timbulan sampah PSP yaitu dengan aktif melakukan kegiatan yang dapat mencegah penggunaan PSP dan didalam kehidupan sehari-hari PSP tidak digunakan. Dengan dicantumkannya peran masyarakat dalam peraturan tersebut, sudah sepatutnya masyarakat sadar akan kewajiban yang harus dilaksanakan karena yang akan mendapatkan dampak positifnya adalah masyarakat itu sendiri. Tidak bisa dipungkiri lagi bahwa masyarakat memang memiliki peran yang amat penting dalam hal pelestarian lingkungan ini. Hal itu salah satunya karena masyarakat pada umumya terdiri dari jumlah yang besar dan akan melakukan kegiatan-kegiatan pemenuhan kebutuhan yang dimana dalam proses pemenuhan tersebut pastinya akan ada interaksi. Dapat diharapkan bahwa apabila terdapat sekelompok masyarakat yang mampu untuk menjaga kelestarian lingkungan sekitarnya maka tidak menuntut kemungkinan masyarakat lainnya juga akan mencontoh msayarakat tersebut sehingga upaya pelestarian lingkungan tersebut dapat berjalan dengan maksimal oleh karena dukungan dari masyarakat itu sendiri.

Pemerintah Daerah Bali telah melakukan upaya dalam mensosialisasikan Pergub Bali No.97/2018 tersebut agar masyarakat sekitar mendapatkan informasi yang valid. Meskipun demikian, masih saja terdapat masyarakat yang tetap menggunakan produk PSP dengan dalih mereka tidak mengetahui adanya larangan menggunakan PSP dalam kehidupan sehari-hari. Untuk meminimalisir adanya masyarakat yang masih menggunakan PSP dalam kehidupannya maka dimuat pula ketentuan sanksi administratif. Sanksi tersebut termuat dalam ketentuan pasal 22 Peraturan Gubernur Bali No.97 Tahun 2018. Sanksi administratif merupakan sanksi dalam bentuk pembebanan kewajiban/perintah yang dikenakan kepada mereka yang melanggar peraturan yang bersifat administratif. Sanksi administratif yang dikenakan kepada masyarakat yang melanggar Pergub Bali No.97/2018 telah termuat dalam pasal 4 ayat (1) Peraturan Menteri Lingkungan Hidup Republik Indonesia No.02/2013. Sanksi tersebut dibuat sebagai bentuk konsekuensi bagi masyarakat yang tidak mau menaati

15 Dewi, Made Heny Urmila Dewi, Chafid Fandeli dan M. Baiquni, "Pengembangan Desa Wisata Berbasis Partisipasi Masyarakat Lokal Di Desa Wisata Jatiluwih Tabanan, Ball." Jurnal Kawistara 3, no. 2 (2013): 129-139 
peraturan sebagai upaya pelestarian lingkungan dengan cara melakukan pembatasan timbulan sampah PSP.

\subsection{Relevansi Pengaturan Peran Masyarakat Dalam Pergub Bali No.97 Tahun 2018 Terhadap Upaya Pengurangan Sampah PSP di Provinsi Bali.}

Perubahan didalam masyarakat merupakan suatu hal dimana masyarakat beranjak dari pola yang satu ke pola yang lainnya. Apabila terdapat suatu perubahan di masyarakat, tentunya masyarakat akan merasa aneh atau bahkan risih, begitu juga dengan perubahan pola prilaku masyarakat Bali yang saat ini dituntut untuk mengurangi penggunaan PSP, mengingat banyak jenis PSP seperti kantong kresek yang sering digunakan dalam kegiatan sehari-hari mereka. Peran masyarakat dalam pembatasan timbulan sampah PSP juga telah termuat dalam Peraturan Gubernur Bali No.97 Tahun 2018. Namun pengaturan peran masyarakat dalam peraturan tersebut dirasa belumlah cukup relevan terhadap upaya pengurangan sampah PSP di Provinsi Bali. Hal tersebut dikarenakan Pergub Bali No.97/2018 masih memiliki beberapa kelemahan. Peraturan tersebut mungkin akan mudah diikuti oleh sebagian masyarakat namun sebagian lagi akan menolak adanya pergub tersebut seperti masyarakat yang merupakan produsen atau distributor plastik sekali pakai. Hal ini dibuktikan dengan dilayangkannya gugatan terhadap Peraturan Gubernur Bali No.97 Tahun 2018. ADUPI (Asosiasi Daur Ulang Plastik Indonesia) mengajukan gugatan ke Mahkamah Agung untuk melakukan uji materiil terhadap beberapa pasal yang ada dalam Pergub Bali No.97/2018.

Jika dianalisis lebih jauh, Pergub Bali No.97/2018 memiliki kelemahan yang bisa dilihat pada ketentuan sanksinya. Ketentuan sanksi yang termuat dalam peraturan tersebut dirasa belumlah dapat memberi efek jera kepada masyarakat. Dalam peraturan itu, bagi pelanggarannya hanya akan dikenakan sanksi administratif saja yang jenisnya telah disebutkan diatas. Sejatinya semua sanksi bertujuan untuk memberikan efek jera, sanksi administratif juga memiliki fungsi instrumental yakni proses preventif dan penanggulangan perbuatan terlarang yang ditujukan terhadap perlindungan kepentingan lingkungan yang dijaga oleh ketentuan hukum yang dilanggar. ${ }^{16}$ Meskipun memiliki fungsi tersebut, sejatinya sanksi adminitratif akan menjadi lebih kuat jika dibarengi dengan ancaman sanksi lainnya, karena dengan adanya banyak ancaman sanksi akan membuat masyarakat semakin takut untuk melanggar suatu peraturan. Jika kita mengacu pada Undang-Undang Tentang Perlindungan dan Pengelolaan Lingkungan Hidup, bisa kita lihat bahwa peraturan tersebut menggunakan beberapa ketentuan hukum yang meliputi ketentuan hukm pidana, ketentuan hukum perdata serta ketentuan hukum administrasi. Itu artinya dalam kasus pelanggaran lingkungan hidup bisa diancam dengan sanksi administratif, sanksi perdata maupun sanksi pidana. Namun perlu diketahui bahwa Peraturan Gubernur tidak bisa memuat ketentuan pidana. Meskipun Peraturan Gubernur merupakan salah satu bentuk peraturan perundang-undangan sebagaimana termuat pada pasal 8 ayat (1) Undang-Undang No.12 Tahun 2011 Tentang Pembentukan Peraturan Perundang-Undangan (untuk seterusnya disebut UU No.12/2011) tetapi karena ketentuan pidana hanya boleh termuat pada Undang-Undang, Peraturan Daerah Provinsi, atau Peraturan Daerah Kabupaten/Kota. Sebagaimana sesuai dengan

16 Nugraha, Made Satria Wibawa. "Pemberian Sanksi Pidana Sebagai Ultimum Remidium Dalam. Undang-Undang Perlindungan dan Pengelolaan Lingkungan Hidup." Jurnal Kertha Wicara 7, no. 2 (2018): 1-11. 
ketentuan pasal 15 ayat (1) UU No.12/2011 yang artinya Peraturan Gubernur tidak dapat memuat ketentuan pidana. Dengan demikian, oleh karena didalam Pergub Bali No.97/2018 hanya memuat sanksi administratif, bisa saja masyarakat merasa tidak begitu takut akan acanaman sanksi yang diberikan sehingga membuatnya enggan mematuhi peraturan tersebut.

Selain pada ketentuan sanksi, mengutip pada tulisan yang berjudul "Discover the Legal Concept in the Sociological Study" yang menyatakan bahwa a good legal product is a legal product with as much material as possible taken from the common law (the public) yang berarti produk hukum yang baik adalah produk hukum dengan materi sebanyak mungkin diambil dari masyarakat itu sendiri. ${ }^{17}$ Jika melihat pada kebiasaan masyarakat Bali yang menyelesaikan suatu konflik atau permasalahan dengan cara kekeluargaan, maka dalam Pergub Bali No.97/2018 juga seharusnya dimuat ketentuan yang mengatur mengenai alternatif dalam penyelesaian suatu sengketa atau permasalahan akibat ditetapkannya peraturan tersebut mengingat bahwa terdapat istilah Penyelesaian sengketa atau permasalahan yang dimaksud bisa melalui prosedur yang disepakati para pihak, misalnya dengan melakukan negosiasi atau mediasi. Cara seperti mediasi dapat dilakukan karena mediasi lebih banyak membicarakan mengenai kesepakatan yang dilakukan para pihak supaya tidak saling dirugikan, namun tetap menjaga kelestarian fungsi lingkungan hidup. ${ }^{18}$ Selain itu dengan mediasi, dapat dilakukan pendekatan kepada masyarakat sehingga dapat memberikan penjelasan lebih dalam agar masyarakat mematuhi peraturan itu yang akhirnya membuat masyarakat yang melanggar juga ikut membatasi penggunaan PSP didalam kehidupannya serta pemberlakukan sanksi dapat diminimalisir.

Dalam Pergub Bali No.97/2018 juga memang sudah berisi ketentuan mengenai peran serta masyarakat seperti dengan aktif melakukan kegiatan yang dapat mengurangi timbulan sampah PSP, tetapi ketentuan tersebut masih bersifat abstrak dan akan jauh lebih baik jika disebutkan tindakan nyata yang dapat dilakukan oleh masyarakat seperti dengan menanamkan prinsip-prinsip yang dapat mengurangi timbulan sampah PSP seperti prinsip 3R, dimana prinsip 3R tersebut juga telah diatur pada pasal 11 ayat (1) Peraturan Daerah Provinsi Bali Nomor 5 Tahun 2011 Tentang Pengelolaan Sampah yang dimana Perda tersebut juga termuat pada bagian mengingat Peraturan Gubernur Bali No.97 Tahun 2018, sehingga sudah ada dasar yuridis untuk memasukkan prinsip 3R pada Pergub Bali No.97/2018. Adapun prinsip 3R tersebut terdiri dari reduce yang merupakan suatu pola untuk mengurangi atau meminimalisir penggunaan produk PSP, reuse yang merupakan kegiatan yang mengurangi barang bersifat disposable, dan recycle yang merupakan kegiatan daur ulang barang sehingga memiliki fungsi berbeda dari sebelumnya. Prinsip seperti itu diperlukan mengingat bahwa peraturan ini bertujuan untuk pembatasan timbulan sampah PSP, dimana prinsip ini bisa dijadikan sebagai landasan awal untuk mencapai tujuan yang diinginkan. Apabila ketiga prinsip tersebut telah berhasil diterapkan maka secara tidak langsung, masyarakat akan mengenal istilah remind dalam upaya pelestarian

17 Sudiarawan, Kadek Agus, Putu Edgar Tanaya, and Bagus Hermanto. "Discover the Legal Concept in the Sociological Study." Substantive Justice International Journal of Law 3, no. 1 (2020): 94-108.

18 Darmayanti, Komang Tri, I Ketut Tjukup dan I Nyoman Satyayudha, "Peranan dan Efektivitas Mediasi Sebagai Alternatif Penyelesaian Sengketa Lingkungan Hidup Di Bali" Jurnal Kertha Wicara 1, no. 1 (2012): 1-7. 
lingkungan. Remind disini maksudnya adalah masyarakat bisa mengingatkan satu sama lain tentang pentingnya melestarikan lingkungan. Sehingga terjalin suatu komunikasi antar masyarakat yang diharapkan mampu meningkatkan kesadaran masyarakat dalam menjaga kelestarian lingkungan khususnya dalam pengurangan sampah plastik sekali pakai.

Dengan menanamkan prinsip-prinsip tersebut diharapkan agar interaksi manusia dengan lingkungan, dalam kehidupan manusia mengalami proses pengamatan terhadap objek, serta tindakan, dan pengalaman dari lingkungannya maupun pengalaman baru yang datang lalu bergabung didalam pikiran sebagai gudang informasi, yang kemudian digunakan untuk memikirkan dan mempertimbangkan semua konflik yang dihadapinya ${ }^{19}$.

\section{Kesimpulan}

Berdasarkan pembahasan permasalahan diatas penulis dapat menarik kesimpulan bahwa Pergub Bali No.97/2018 memiliki tujuan untuk melestarikan lingkungan hidup dengan cara membatasi timbulan sampah PSP, dimana didalamnya memuat peran serta masyarakat Bali dalam bentuk hak dan kewajiban untuk ikut membantu pemerintah dalam mensukseskan tujuan tersebut dan memuat ketentuan sanksi berupa sanksi administratif yang bisa dikenakan kepada masyarakat yang berani melanggar peraturan tersebut. Meskipun demikian, pengaturan peran masyarakat dalam Pergub Bali No.97/2018 dirasakan belum cukup relevan sebagai upaya pembatasan timbulan sampah plastik sekali pakai (PSP) dikarenakan peraturan itu memiliki kelemahan berupa tidak dimuatnya upaya mediasi sebagai salah satu cara menyelesaikan sengketa padahal masyarakat Bali lebih sering menyelesaikan suatu masalah dengan cara kekeluargaan. Peraturan ini juga tidak dimuat prinsip-prinsip yang dapat mendukung masyarakat dalam pembatasan timbulan sampah plastik sekali pakai (PSP) serta ketentuan sanksi didalamnya dirasa cukup lemah karena tidak bisa dimuat sanksi pidana sehingga membuat sebagian masyarakat tidak takut untuk melanggarnya.

Saran yang bisa diberikan berdasarkan pada hasil dan analisis pembahasan mengenai permasalahan tersebut diatas, diharapkan Pemerintah Daerah Bali kelak dapat menerbitkan Peraturan Daerah Provinsi mengenai pembatasan sampah plastik sekali pakai (PSP) yang memuat ketentuan sanksi pidana didalamnya. Hal ini dapat dilakukan karena Pemerintah Daerah berwenang untuk mengurusi daerahnya sendiri. Masyarakat sebagai elemen penting dalam suatu ekosistem lingkungan hidup sudah sepatutnya menjaga dan melestarikan lingkungan hidup. Maka dari itu sebaiknya masyarakat tidak melanggar peraturan yang ada sebagai upaya untuk melestarikan lingkungan, disamping akan terbebas dari ancaman sanksi maka dengan tidak melanggar peraturan tersebut secara tidak langsung masyarakat juga ikut berpartisipasi dalam usaha pelestarian lingkungan hidup.

19 Ariwidodo, Eko. "relevansi pengetahuan masyarakat tentang Lingkungan dan etika lingkungan dengan partisipasinya dalam pelestarian lingkungan." NUANSA: Jurnal Penelitian Ilmu Sosial dan Keagamaan Islam 11, no. 1 (2014): 1-20. 


\section{DAFTAR PUSTAKA}

\section{Buku}

Efendi, S.H.I., M.H., Dr. Jonaedi dan Prof. Dr. Jhonny Ibrahim, S.H., S.E., M.M., M.Hum., Metode Penelitian Hukum Normatif dan Empiris Edisi Pertama, (Depok, Prenadamedia Group, 2016).

Keraf, A. Sonny, Etika Lingkungan Hidup, (Jakarta, Penerbit Buku Kompas, 2010).

Takdir, Rahmadi, Hukum Lingkungan di Indonesia, (Jakarta, PT. Raja Grafindo Persada, 2012).

\section{Jurnal Ilmiah}

Aditya, I Gst. Ngr. Agung Krisna. "Pergub Bali Nomor 97 Tahun 2018 Dalam Paradigma Etika Ekosentrisme." Jurnal Ilmiah Widya Sosiopolitika 1, no. 2 (2019): 109-119.

Ariwidodo, Eko. "relevansi pengetahuan masyarakat tentang Lingkungan dan etika lingkungan dengan partisipasinya dalam pelestarian lingkungan." NUANSA: Jurnal Penelitian Ilmu Sosial dan Keagamaan Islam 11, no. 1 (2014): 1-20.

Darmayanti, Komang Tri, I Ketut Tjukup dan I Nyoman Satyayudha, "Peranan dan Efektivitas Mediasi Sebagai Alternatif Penyelesaian Sengketa Lingkungan Hidup Di Bali" Jurnal Kertha Wicara 1, no. 1 (2012): 1-7.

Dewi, Made Heny Urmila Dewi, Chafid Fandeli dan M. Baiquni, "Pengembangan Desa Wisata Berbasis Partisipasi Masyarakat Lokal Di Desa Wisata Jatiluwih Tabanan, Ball." Jurnal Kawistara 3, no. 2 (2013): 129-139

Hasibuan, Rosmidah. "Analisis dampak limbah/sampah rumah tangga terhadap pencemaran lingkungan hidup." Jurnal Ilmiah Advokasi 4, no. 1 (2016): 42-52.

Karuniastuti, Nurhenu. "Bahaya plastik terhadap kesehatan dan lingkungan." Swara Patra 3, no. 1 (2013): 6-14

Kubontubuh, Ekapria Dharana. "Bali Bebas Sampah Plastik (menuju “Clean and Green Island")." Jurnal Bali Membangun Bali 2, no. 1 (2019): 41-46.

Nugraha, Made Satria Wibawa. "Pemberian Sanksi Pidana Sebagai Ultimum Remidium Dalam. Undang-Undang Perlindungan dan Pengelolaan Lingkungan Hidup." Jurnal Kertha Wicara 7, no. 2 (2018): 1-11.

Purwaningrum, Pramiati. "Upaya mengurangi timbulan sampah plastik di lingkungan." Indonesian Journal of Urban and Environmental Technology 8, no. 2 (2016): 141-147.

Putri, Niluh Wiwik Eka. "Komunikasi Sosial dalam Mensosialisasikan Penetapan Kebijakan Gubernur Bali Tentang Pembatasan Timbulan Sampah Plastik Sekali Pakai." Jurnal Nomosleca 5, no. 1 (2019): 44-57.

Sudiarawan, Kadek Agus, Putu Edgar Tanaya, and Bagus Hermanto. "Discover the Legal Concept in the Sociological Study." Substantive Justice International Journal of Law 3, no. 1 (2020): 94-108.

Tjukup, I. Ketut, Dewa Nyoman Rai Asmara Putra, Nyoman A. Martana I. Putu Rasmadi, P. Arsha, and Kadek Agus Sudiarawan. "Penyelesaian Sengketa Lingkungan Hidup Melalui Mekanisme Acara Gugatan Perwakilan Kelompok (Class Action)." ADHAPER: Jurnal Hukum Acara Perdata 3, no. 2 (2018): 245-260.

Wesnawa, I. Gede Astra,"Penerapan Konsep Tri Hita Karana dalam Lingkungan Permukiman Perdesaan (Kasus Kabupaten Badung Provinsi Bali)." Jurnal Bumi Lestari 10, no. 2 (2010): 295-301. 


\section{Peraturan perundang-undangan}

Undang-Undang Dasar Negara Republik Indonesia Tahun 1945

Undang-Undang Republik Indonesia Nomor 32 Tahun 2009 Tentang Perlindungan dan Pengelolaan Lingkungan Hidup, Lembaran Negara Republik Indonesia, Tambahan Lembaran Negara Republik Indonesia

Undang-Undang Republik Indonesia Nomor 12 Tahun 2011 Tentang Pembentukan Peraturan Perundang-undangan, Lembaran Negara Republik Indonesia, Tambahan Lembaran Negara Republik Indonesia

Peraturan Menteri Lingkungan Hidup Republik Indonesia Nomor 02 Tahun 2013 Tentang Pedoman Penerapan Sanksi Administratif Di Bidang Perlindungan dan Pengelolaan Lingkungan Hidup

Peraturan Daerah Provinsi Bali Nomor 5 Tahun 2011 Tentang Pengelolaan Sampah

Peraturan Gubernur Bali Nomor 97 Tahun 2018 Tentang Pembatasan Timbulan Sampah Plastik Sekali Pakai

Internet

Data dan Sumber Sampah di Bali Tahun 2019,https:// balibersih.com/2019/07/04/data-dan-sumber-sampah-di-balitahun-2019/

Timbulan Sampah Nasional Capai 64 juta ton per Tahun, https://ekonomi.bisnis.com/read/20190221/99/891611/timbulan-sampahnasional-capai-64-juta-ton-per-tahun. 